\title{
Navigating wahine Kāi Tahu methodology
}

\author{
Kerri Cleaver (Kāi Tahu, Kāti Māmoe, Waitaha), University of Otago, Aotearoa New Zealand
}

\begin{abstract}
INTRODUCTION: Indigenous research is diverse and rich with multiple epistemological understandings. There is no one template for how we go about this. Shut out from the hallowed halls of academia for generations, Indigenous wāhine have taken up the diversity of our perspectives and, in doing so, space has been created to compose from our own contexts.

APPROACH: This article explores one way of engaging in research as an Indigenous social worker. It is the sharing of my own process of mapping out my legitimacy in an academic space and in a Māori space as a colonised wahine Kāi Tahu caught in the dual complexities of decolonising and living in this time. Navigating wāhine Kāi Tahu methodology is about the journey to create from my own context, honouring the process and the voices and experiences of the wāhine Kāi Tahu who shared in my research. The process includes the melding of traditional Kāi Tahu stories into a methodological framework in Indigenous ethnography.
\end{abstract}

KEYWORDS: Herstory; mana wāhine; Kāi Tahutaka; Mahika Kai; Pūrākau; social work; autoethnography

\section{Ko Aoraki te Mauka \\ Ko Aparima te awa \\ Ko Takitimu te waka \\ He wāhine Kāi Tahu ahau \\ Ko Kerri Cleaver tōku ikoa}

This article explores one way of engaging in research as an Indigenous social worker. It is the sharing of my own process of mapping out my legitimacy in an academic space and in a Māori space as a colonised wāhine Kāi Tahu, caught in the dual complexities of decolonising and living in this time. My hope is that it will open up possibilities and provoke discussion around our multiple authentic voices. It is not intended as a template for other people's research methodology, nor is it intended to direct the way in which research should occur. It is the exploration of self, of one wāhine in the context of cultural connectiveness and storytelling.
My $\mathrm{PhD}$ research (not yet completed) is a collection of mana wāhine pūrākau. These are specifically the stories given visually and orally about the belonging and identity journey of wāhine Kāi Tahu who have been through the state foster care system. In this journey of research, I am both emic and etic (insider and outsider), telling my own pūrākau through autoethnography, but also as an outsider to each wahine's journey. The methodology developed to hold these taoka (treasures) is the combining of a set of imperatives held in a korowai (cloak) of Kāi Tahutaka.

\section{Epistemology}

\author{
Hinepipiwai \\ Hinepipiwai was part of an exploring party \\ travelling through the Whakatipu-ka-tuku, \\ (Hollyford to Whakatipu) trail. She attempted \\ to climb the highest peak to get an extensive
}

AOTEAROA NEW ZEALAND SOCIAL WORK 32(3), 5-16.

CORRESPONDENCE TO: Kerri Cleaver Kerri.cleaver@tiakitaoka.nz 
view over the region. When she was not able to reach the summit, she sat at the highest point to admire the view. The mountain was subsequently known as Te Taumata-oHinepipiwai.

In my own world, wāhine and Kāi Tahu take centre stage. From this perspective, world history is re-written as herstory and ourstory and a re-balancing of gender and sexuality occurs to make space for all, inclusive of takatāpui and LGBTQI+. The seminal works by Matahaere-Atariki (1997), hooks (1989), Spivak (1988), Johnston and Pihama (1994), Wanhalla (2015) and Lorde (2018) directed me towards a methodology that recognises the footprint of colonisation and imperialism, but also talks back to it in a specific way centring silenced voices. Audre Lorde (2018) said "you cannot dismantle the master's house with the master's tools" which I interpret as a call to the marginalised to find their / our own tools (Lorde, 2018). Personally, this was the call to both dismantle a house built on my whenua where once stood our kaik (villages) and shelters that held our wāhine Kāi Tahu truths and to use our abundant collection of Kāi Tahu tools to rebuild through our own pūrākau. Lorde's words provoke us towards resistance against acts of Othering and, in the academic environment, activate against the expectations that methodology and research needs to submit and conform to the western patriarchal view (Said, 1979).

Kaupapa Māori Research is one version of a decolonising methodology proven to be both effective and rich in research and reclaiming of Māori knowledge and rights (Bishop, 1998). Kaupapa Māori Research is the foundational collective recognition of Māori epistemology as legitimate and academically stringent and provides the footing by which whānau, hapū and iwi are able to develop our own tools and understandings centred in our own experiences of who we are (Smith, 2013). The tools and understandings for my research was clearly Kāi Tahutaka and flow on as a natural, localised response where our own ways of being are core.

The pūrākau of Hinepipiwai resonated with the idea of preferencing wāhine Kāi Tahu stories and specifically conferred the urge and need for relevant methodology that future gazed with a wide view, while also understanding that there will always be some unseen elements (hidden behind the mountain), making space for research surprises and variations. Hinepipiwai understood that, in order to safely navigate the way forward as they travelled along mahika kai trails, it was important to take the time to have some oversight forward and back.

\section{Kāi Tahutaka}

Epistemology is how we think about knowledge, justify why we align to certain theories of knowledge and rationalise our beliefs. The act of defining my research to wāhine Kāi Tahu and my self-defined declaration that wāhine Kāi Tahu are at the centre of my world leads in to my certainty that Kāi Tahutaka is the epistemological positioning of this research.

As a white-passing wahine Kāi Tahu, I have spent many years grappling with microaggressions against me from both Māori and Pākehā that seek to question the authenticity of my whakapapa and reduce me to their pre-determined definitions either through blood quantum or through a series of tick boxes of authentic Māori in which, in their eyes, I inevitably fail. Admittedly these microaggressions would never stack up to the overt racism that I see people of colour (POC) subjected to on a regular basis. I would never seek to invalidate the very real racist experiences and harm that POC deal with, and of which I have little experience, as a white-passing Indigenous wāhine. However, in understanding my own iwi-centric standing, it is most likely that my own encounters of attacks against my culture and identity have steered me towards my staunch Kāi Tahu pou (stake in 
the ground) where I intentionally align with the words of Tā Tipene O'Regan:

I regard myself as Ngāi Tahu. I regard myself as a New Zealander of Irish descent-so I value hugely the western tradition that lies behind that Irish descent, and being a New Zealander ... but the thing that makes me uniquely of this place-is my Ngāi Tahu descent. I'm not interested in that being part of a general Māori descent in particular. (Tipene O'Regan in O'Regan, 2001, p. 55)

An important distinction that I make in taking a Kāi Tahutaka epistemological position is that the researcher and coresearchers do not need to be fluent in Kāi Tahutaka. The truth of being Kāi Tahu is unprecedented land loss, cultural knowledge loss and language loss. If Kāi Tahu are lucky enough to have maintained the links and knowledges to whenua and traditions, these are the exceptions and not my own experience. So, to hold up the mana of each wahine in the project, the Kài Tahutaka epistemological position is openly a growth and learning space.

I was drawn to the mahika kai trails, to our Kāi Tahu traditions of travel, gathering kai and resources and sharing of knowledge, stories and resources. Mahika kai is a complex system of resource and food gathering that spans across the takiwā (tribal boundary) and is controlled by whakapapa and ahi kā principles (Williams, 2004). Kāi Tahu mahika kai trails are centred in whakapapa which is the generational transmitted connections between us and our tūpuna, between animate and inanimate and in the relational ties to tikaka, philosophies (epistemologies) and herstories.

Kāi Tahu regularly, to this day, engage in mahika kai journeys, the most obvious being yearly trips to the Tītī islands. The coming together of communities, on the islands or in inland mahika kai points have always been about more than resource collection. It has also been points in time that allow sharing of stories, marriages and resources. Mahika kai is utilised in my research as the symbolic representation of traditional systems of coming together and communication. During the inland journeys of which Hinepipiwai was on when she climbed the mountain to look over the trail, Kāi Tahu had poutohu/ signposts that were track markers. Often these were tī kōuka/cabbage tree which were also an important source of carbohydrates for Kāi Tahu. The tī kouka is used as both the symbol of pou holding up the wharerau/house and also as poutohu symbols for the research journey. The poutohu are Mana wāhine; Whakaahua (used to represent photographs); Pūrākau; autoethnography and social work.

The wharerau is a round house which was used traditionally by Kāi Tahu as both temporary dwellings but also as a place of learning and storytelling. It is a symbol of this and represents the nature of our differing settlements and that, as Kāi Tahu, we developed a system of sustainability around our resources that spanned the Kāi Tahu boundaries that make up our takiwā.

The below visual methodology represents the wharerau as both the space where the research occurs but also the mahika kai trails that is the journey itself. Through the process of mapping out what it means to be Kāi Tahu and therefore what Kāi Tahutaka actually is in my research project, I draw on the Ngāi Tahu cultural principles: Whanaukataka; Manaakitaka; Tohukataka; Tikaka and Rakatirataka which are named as principles inside the wharerau as the relationship building between researcher and co-researcher.

The Puaka star constellation sits outside of the wharerau and is the process of presenting the whakaahua, pūrākau and autoethnographical accounts of the mana wāhine that have been part of the research. In this particular article, Puaka is only briefly discussed towards the conclusion. 


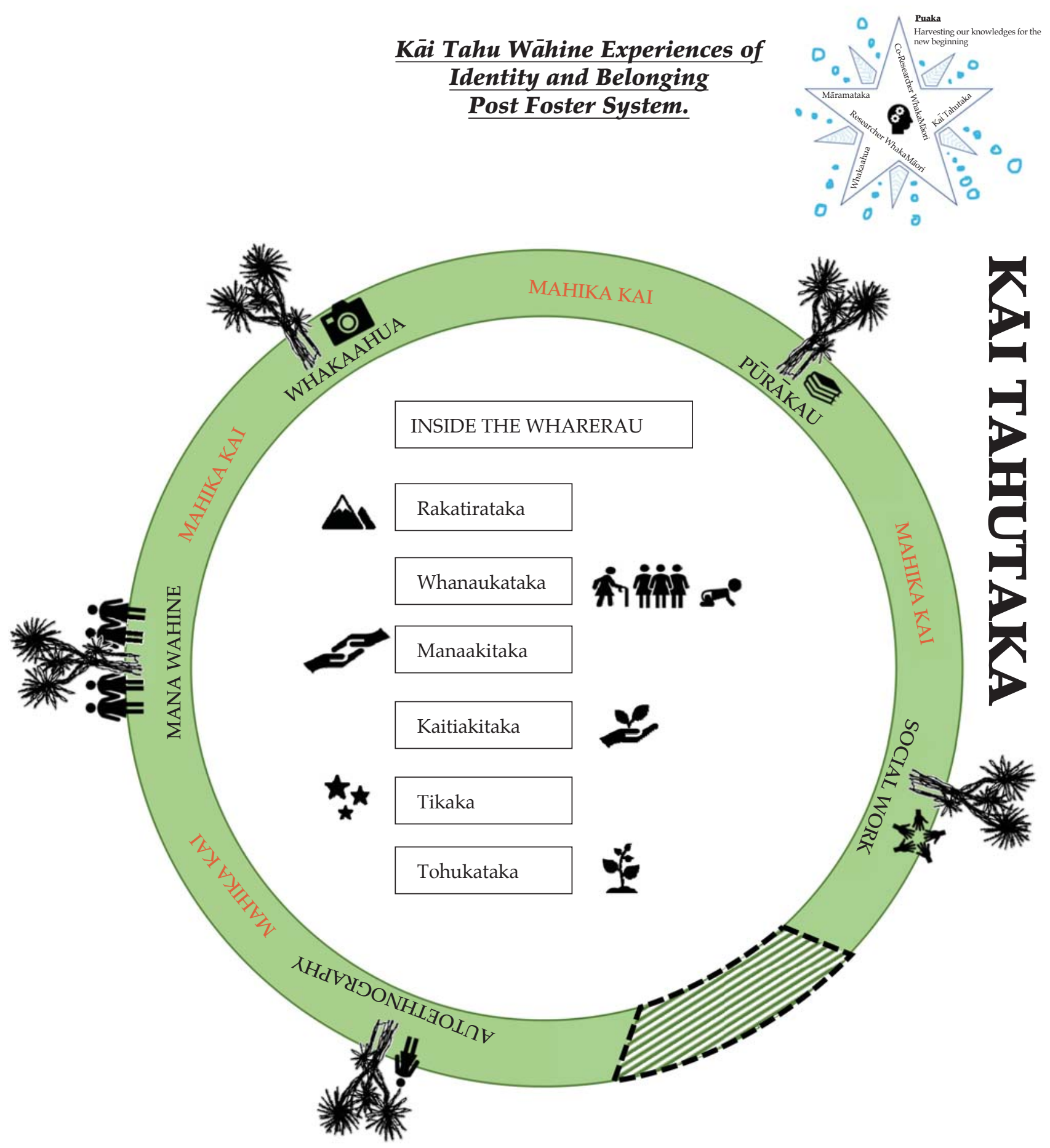

Each poutohu is expanded on in this paper to highlight the interdependencies and complexities of each as they relate to Kāi Tahu herstorically, contemporarily and in their interactions with each other.

\section{Mana wāhine}

Written histories are not without bias or personal agenda, they are put together according to the norms of the age and 
through the lens of the writer who holds the pen. Through the articulation of written histories, the multiple truths of history / herstory/theirstory are unlikely to be seen or heard from those rendered voiceless. Spivak coined the term subaltern for those that remain invisible and silent, which Indigenous women both currently and historically readily and consistently remain (Spivak, 1988). Wahine Kāi Tahu have also struggled in this confinement of enforced silence where she is spoken about, and spoken for, but rarely given the space to speak herself (Matahaere-Atariki, 1997). For those who know wahine Kāi Tahu rakatira, this may be a questionable statement as there are those that are able to carve out space to talk and sometimes be heard. However, we have largely remained omitted from past literature and like many Indigenous women have been misrepresented, had our theories suppressed and as such many of what are important wahine narratives have been listed as "myths" rather than truths (Jenkins \& Pihama, 2001; Murphy, 2013).

The core of the issue where women, Indigenous women, Māori women and Kāi Tahu women find themselves secondary to a dominant discourse is illustrated by Wynter (2003) as the creation of the truth of a superior race exhibited as Man. For Wynter, Man is born out of an "axis of subjugation" centred in the "bio-economic man" where dominating white supremacist meets neoliberal capitalism. The results of this are world economic exploitation, gendered oppression and, for Indigenous peoples including Māori, this sits against the backdrop of colonisation. Wynter's work has been essential in my developing an understanding of the way in which multiple systems work against the wahine Kāi Tahu in her attempts to take her rightful place at decision making tables, in the centre of debates around her body or her parenting or in her connection and responsibilities to whakapapa.

When researching in the space of child protection and state foster systems an analysis of the way in which Man is preserved on top while justifying enduring dehumanisation of all others is fundamental to how we go about research which resists rather than replicates. Wynter (2003) argues that the re-enforcing of Man by Man is purely economic and power based and coincides with the current colonial distribution of wealth, ongoing theft of land or resources, labour atrocities and the mistreatment of children which have all followed from past constructions of women as hysterical and POC as biologically inferior.

Examples of the way in which Wynter's definitions of Man have sought to oppress Māori women are found in our records. In the 1880s, Pākehā women in the Women's Christian Temperance Union determined Māori participation in the organisation while demanding their cultural assimilation including agreement to not take moko kauae (chin tattoo) (Else, 1993). Through Ngā Komiti Wāhine, Māori women, including wāhine Kāi Tahu sought participation in land rights and tribal affairs including addressing family harm, substance abuse and traditional skills. Through the 1950s until present times, the Māori women's welfare league continued to seek a realignment to a gendered imbalance of power while supporting the whānau system. All these attempts by wāhine Māori to be heard have been directly challenged with attempts at silencing from an Aotearoa version of Man.

The re-balance of power does not occur as a natural course or event and the struggle towards equality and diversity rights requires intentional attention, as highlighted by Mikaere:

The challenge for Māori, women and men, is to rediscover and reassert tikanga Māori within our own whanau, and to understand that an existence where men have power and authority over women and children is not in accordance with tikanga Maori. (Mikaere, 1994, p. 149) 
For this research, the placing of mana wāhine as a poutohu is a given and absolute intentional act of centring our wāhine Kāi Tahu, in all our multiple versions of ourselves past, present and future. Kāi Tahu such as Angela Wanhalla (2015) are now piecing together the remnants of hidden wāhine pūrākau hoping to provide our mokopuna with a clearer narrative of who we are as wahine, seeking the stories of our strength and endurance.

An exciting Kāi Tahu development in storytelling is $K \bar{a} H u r u$ Manu, the collection of place names and meanings, a resource which is now openly available. For a project that utilises mahika kai trails and storytelling in methodology this resource has provided many wāhine Kāi Tahu stories from around our takiwā. Some initial analysis of place-names in Kā Huru Manu affirms the unsurprising reliance on resources as the majority of our places are named after resources rather than people, one of my favourites being Te-Kaika-okēroa, the home of mosquitos. A clear warning to cover up if visiting that spot. The collection also includes some really significant stories of wāhine Kāi Tahu who were warriors, swimmers, guides and heroes, including Kaiamio, Hakitekura and Hinepipiwai. These treasures are threaded through my research and support the wāhine Kāi Tahu who have chosen to share their journeys of identity and belonging. The importance of mahika kai alongside mana wăhine is connected to our responsibilities to our mokopuna, acknowledging Wynter's connection between economics, land, resources and the misuse of power. In order to truly calibrate a world where the Indigenous woman is heard, we must remember the meaning of whakapapa as it pertains to the whenua.

Mana wāhine as a Poutohu is the layering of herstories and pūrākau across time but as a specific purposeful intention to preference mana wāhine and grow sharing the stories of our tūpuna taua while sharing our present day experiences.

\section{Pūrākau}

Recently while driving through Central Otago with my whānau, we drove past a sign saying "Kōpūwai Conservation reserve." I launched into storytelling mode telling of Kōpūwai and Kaiamio, a giant and a wahine Kāi Tahu. Kaiamio had cleverly escaped the kidnapping from Kōpūwai after he had killed all her hunting party and after returning to her kaik she returned with a large party and killed Kōpūwai through both strength and stealth. The importance of Central Otago to Kāi Tahu has grown on me through my PhD journey and through the discoveries of our stories and our connections. This was made obvious in that moment and, while we did not make the time to visit the site itself that day, the next time we pass this particular piece of whenua we will have factored in time to visit the site itself and share our thoughts about Kōpūwai and his two dogs, now turned to large stones. Knowing the stories of our tūpuna wāhine and being able to weave them in to our everyday not only strengthens us in the now but also us in the future.

Pūrākau/storytelling has a whakapapa in my life, in the stories of my tūpuna, the stories of my own parentage and the stories that I have told and chosen not to tell. While at the time I could not articulate the importance of pūrākau I now understand that pūrākau started my own journey of connection and belonging after the foster care system. This occurred when I was in my early 20s and studied at Whitireia Art School. Each year in the programme, students were asked to work towards an end of year exhibition. The year I was there the exhibition was Ko Wai Au, an exploration of who I was and where I came from. Until that time I had not explored this and my inward view of self was captured within two generations of lived experiences. The voyage through that year lead me to dive deeply in to archival information but also on a trip south to stand on my marae, to reconcile intergenerational experiences and hear of tūpuna that I had not known of but who are 
a part of me. I looked deep in to the stories that led me to be me. That was now two decades ago and the importance of pūrākau has remained with me.

The work of Leanne Simpson, Dancing on our Turtle's Back (2011), advocates for the listening with open hearts and feeding the fires or what we would call ahi kā.

To Simpson, storytelling is intrinsically tied to the relationality we have with land and "land as practice" while also providing theories that we do not find is western academia. Storytelling for Simpson is a collective rising of Indigenous being and she asserts:

Part of being Indigenous in the $21^{\text {st }}$ century is that regardless of where or how we have grown up, we've been bathed in a vat of cognitive imperialism, perpetuating the idea that Indigenous Peoples were not, and are not, thinking peoples-an insidious mechanism to promote neo-assimilation and obfuscate the historic atrocities of colonialism. (Simpson, 2011, p. 32)

Other Indigenous women have equally asserted the use of storytelling including social worker and academic Kovach (2010) who states that storytelling sits in Indigenous methods which should incorporate Indigenous paradigms. Upon our own shores of Aotearoa, the work of Somerville (2010) and Lee (2009) both describe the diverse benefits of storytelling in research and as a continuation of our Māori theories. Somerville references the imaginative occupation through storytelling where we are able to see our connections even when dislocated from our lands.

Perhaps our greatest modern-day Māori storyteller, who straddles success as orator and academic is Moana Jackson who so eloquently and powerfully delivers key messages and ideas through the use of pūrākau. The way Jackson weaves his own stories, his ancestors stories and the stories gathered through his encounters with peoples of the world evokes emotions and feelings that create thinking and reflection (Jackson, 2013). The pūrākau that Jackson shares incorporates autoethnography and pūrākau together delivering in a way that is often missed through processes such as ethnography and data analysis.

Like all the poutohu of this research, pūrākau doesn't stand alone and is intertwined through the others. The layers of pūrākau gifted by the wāhine Kāi Tahu visually and orally talk of navigating belonging and identity and richly weave in with our whenua and our reclaiming of who we are in relation to our tupuna and mokopuna. These are also woven into the pūrākau of our tūpuna wāhine.

\section{Whakaahua Taoka}

Whakaahua/photography has its own whakapapa for Māori and for Kāi Tahu. The choice to use whakaahua in the methodology is a way of engaging in contemporary forms of storytelling and acknowledges the work that our visual and digital artists have taken to connect us to our stories and our whenua.

As subject of the colonial gaze, the depictions of the Indigenous women as sexualised, submissive and exotic representations of a lesser woman is well documented (Yegenoglu, 1998). Examples of this are the bare-breasted victim; the wrinkled and aged smoking kuia; and the child-bearing savage which date back to early photography. Painters such as Goldie and Steele re-enforced grand narratives of the powerless Indigenous wahine and in doing so made challenges to the inherent mana of wāhine Māori (Johnston \& Pihama, 1994; Wanhalla, 2015).

Photographical ethnography, introduced in New Zealand as early as 1848, presented a dichotomy of positive and negative representations of our tūpuna (Mills, 2009). Wāhine Kāi Tahu were exploited in the 19th century, portrayed as the "beautiful half caste" through early tourism, in what 
Wanhalla (2015) describes as an essential tool of assimilation. Wanhalla (2015) equally implicates ethnography here in the historical erasure of the wāhine Kāi Tahu herstory. Through the objectification of the native, names and stories were insignificant and grand narratives of racial types prevailed as though cartographs and photographs held universal truths.

Photography as a methodological choice by ethnographers such as Anderson (1923) and Bateson and Mead (1942) continued casting the researched as subjects/objects removed from the research or researcher. The camera held the space between $u s$ and them, allowing the researcher to remain unattached and without any requirements to engage in any reflective gaze of selfas-researcher. Attempts to move from oppressive visual data collection to inclusive forms of research were led by John Collier and the creation of photo elicitation, named Visual Anthropology in the 1950s (Harper, 2003). These recent developments in photographical research tools have been tied to participatory inclusion and antioppressive ethnography developing from photo novella, foto novella or to Participatory Action Research (PAR) such as Photo-voice (Wang \& Burris, 1997).

Alternatively through the last 180 years, Māori were ourselves directing portraits and developing our own skills and tools around the photography and the digital arts. Photographs have become historical/ herstorical objects of significance to Māori and Kāi Tahu as evidenced in wharenui around the country, demonstrating the early adaptations to Māori culture making way for contemporary tools and skills (Brown, 2008). Kāi Tahu photographers and artists have cultivated their arts is the same space made real by mana wāhine who have been rebuilding traditional knowledges. Art as the culturally significant was a purposeful part of a Kāi Tahu social structure where stories and herstories are told through waiata, pūrākau, weaving, carving and painting. Writing Indigenous women back in to history / herstory through the arts is an international movement towards the re-establishment of these Indigenous women's knowledges (Kermoal, 2010). Re-membering through art and image is in resistance and response to being dismembered through colonising domination (Kermoal, 2010). Some wāhine Kāi Tahu photographers engaged in re-membering, reclaiming and remembering are Conor Clarke, Fiona Pardington and Rachel Rakena, contributing in stories of identity and belonging and incorporating being into seeing and photography. Through visual recognition of: whenua and nature as living and having life-force; the challenges of the post-colonial wahine; the importance of our cultural artefacts; and the connections to whakapapa, these wāhine explore through the camera what it means to be wāhine Kāi Tahu (Brown, 2008; Mills, 2009).

In an article exploring wāhine photographers, Mills (2009) attributes digitisation of images by wāhine to the re-emergence of mana wāhine centred cosmologies and a writing back to the didactic binary genderised myth made truth through colonial discourse. For Mills (2009) and our wāhine Kāi Tahu photographers, the image is taoka and wāhine voice and growth with the potential of lifting wāhine Kāi Tahu to the status of "preciousness" and "potentiality" and is part of Kāi Tahu cultural remembering (Pardington, 2013). Māori digital production also provides a form of resistance to cultural reductionism of an authentic Māori placed as close as possible to that of our pre-colonial tūpuna.

The use of photography in the research is an intentional and purposeful and part of the herstoric movement towards diverse representations of our selves. For the wāhine who have been part of the research, the use of a camera has been meaningful and layered in rich narratives of places, people, resources, art and spanning time. This was in some ways unintentional in its depth but has melded completely with the wider wāhine Kā Tahu persistent call to be heard. 


\section{Autoethnography}

Navigating adulthood and the transition into adulthood was difficult for me and fraught with many obstacles as a state ward exited from the system at age 17 . The desire to research and write about my own experiences came from a growing understanding of what had been done to me and developed further during my research in my postgraduate diploma in Child Centred Practice. Working in child protection has highlighted the difficulties that lay ahead for the 'us' in the post-foster-care system and that my own experience was not isolated. There is research specifically looking at transitions internationally and in Aotearoa but very few researchers had looked solely through an Indigenous lens.

Autoethnography as part of my methodology allowed me, as the researcher, the space to share my own story, intertwined with that of my sisters. Eight months into my PhD, my sister, my only sibling, died suddenly. The impact that this had on my own story was significant as I went about the task of burying her and was confronted with the multiple ways in which disconnection to culture and identity play out even at the age of 46 . We had both been served a life sentence through our experiences in the state foster care system and the repercussions continued to play out throughout our adult lives. In each of our ways we had been chipping away at the barrier created through the oppressive institutional systems of and from the foster system but, in the end, the quiet (or for me, not so quiet) chipping away only put a small dent in that barrier. In this I needed the research to allow space to truly be an insider and tell our own version of our journeys.

I give credit to Bochner and Ellis (2016) in their early work developing autoethnography as a research methodology. They asserted that purposeful research did not have to follow patterns of ethnography which are historically seeped in issues of Othering regardless of attempts towards participatory and inclusive methods. Autoethnography is a powerful and meaningful tool of doing research that allows Indigenist and Indigenous ways of thinking and feeling and validates the story in its wholeness (Ellis, 2004; Kidd \& Finlayson, 2009). Autoethnography isn't new to Indigenous communities who have utilised storytelling over centuries and applied these as learnings throughout generations, drawing meaning and value from them in the modern world as much as in the past (Simpson, 2011). Autoethnography has helped and supported diversity, Indigenous voices, recognition of the experiences of People of Colour and space for takatāpui/LGBTQI+ to be heard by reducing the limitations of traditional research methodologies and making space for multiple epistemologies. But, perhaps in my own research, the fundamental singular achievement of autoethnography is the push back at data collection and data analysis which became standardised without any real critique around the purpose and meaning relevant to each qualitative research project (Kidd \& Finlayson, 2009).

Data collection and analysis may be important in many research projects but, when considering research that utilises pūrākau/storytelling, the question I apply is "Does stripping back a story to words and themes enhance or reduce the mana of that story and its' orator?" I have woven wāhine Kāi Tahu pūrākau through my research which are examples of autoethnography intergenerationally. These stories in their wholeness are allowed to grow and change from generation to generation and do not represent one truth. Here data analysis is discarded and a practice of response, reflection and personal insight replaces it. Ellis (1999) calls this evocative autoethnography where the author writes to pull out emotion, feelings and connection and the reader makes associations with the text or performance, drawing on their own stories through their own emotive responses. Mello suggests that, to superimpose a data analysis method over narratives such as these, 
mistakenly implies one individual's ability to "authentically represent" another person's descriptive value (Mello, 2002, p. 233).

In an Aotearoa context, researchers, including Kidd and Finlayson (2009) in their research with nurses who experience mental illnesses, have struggled with the approach to analysing interviews / stories / pūrākau and found that holding stories whole can take the reader closer rather than further away from the stories (Kidd \& Finlayson, 2009). Kidd and Finlayson found participants could readily analyse their own stories, respond to them and were able to work effectively with the researcher to collaborate and co-create what would be presented. Kidd's response to the research ethical dilemma of sharing power with the participant was to hold the stories whole and write poems or vignettes in response to them from her interpretation.

I shared this ethical dilemma and have utilised a mix of separately telling my own story and enabling the wāhine Kāi Tahu to tell their own in whatever way they decide. This means that they may choose not be included in the final $\mathrm{PhD}$, they may choose to be represented by a photograph and not the pūrākau that runs alongside it, or they may choose to write themselves into their own story. As a researcher, I am willing to move and shift to the needs of the participants / co-researchers and to fully engage in the principle of Rakatirataka. For me the process of whakawhanaukataka is the outcome, not what is produced.

\section{Social work}

The anchor of my professional self is my ethics and professional standards as a social worker. Every part of the 10 competency standards of the Social Workers Registration Board (SWRB, 2020) is fundamentally important to both my social work self but also to the way in which I engage in research and commit to the social justice struggle against oppression in all its various forms. The meaning of research as a wāhine Kāi Tahu for me is the transformation that can occur at all levels, micro, meso and macro. This is social work, seeking change and doing so in a manner that upholds mana.

As a social worker, I am trained and I am registered with the SWRB. This includes signing a code of ethics and a set of practice standards. They are the framework which expects and demands we do our job in a way that upholds the mana and dignity of our clients. Our code of ethics state integrity and honesty, respect for Māori as tangata whenua and building trust.

The 10 core social work competencies are all really important to good practice. Competency 1 (Competence to practise social work with Māori), has some vital expectations that relate to our everyday life, our practice and for this project, to research. The stated principles of Te Rangatiratanga, Te Manaakitanga and Te Whanaungatanga (SWRB, 2020): defined broadly this requires us to act in a manner that is mana enhancing, respectful, encouraging and warm, selfdetermining and culturally sustaining. As social workers this is an important template for practice that affirms strength-based, whānau-led work even in the toughest of situations. As a social worker researcher these principles are equally important. Pūrākau sits in the essence of my social work practice. From early on in my training Narrative Theory, Strengths based and Rangatiratanga became the key parts of how I wanted my practice to develop. These combine to create a framework that centres the voice of the whānau that I work with. That included making space for whānau to tell their stories, be heard and to have a response that supports them.

\section{Puaka}

I have represented the collection of stories and photographs as Puaka, the star constellation that signals the Kāi Tahu New Year and represents a time of harvesting and beginning. As discussed across this article, the data collection and data analysis for this project is a move away 
from standardised qualitative methods. The Puaka image in the visual methodology is the fluent reality of how we work together with understanding and care, respecting these are the treasures of the Kāi Tahu wahine who gifted their time and expertise.

\section{Conclusion}

Navigating a methodology that combined a number of elements deemed important to me was no easy feat. It took a lot of work and a fair amount of going around in a spiral until I consolidated my thinking and feeling to something that I could be happy with. This was not done in collaboration with my participants as the process of engaging participants has been slow and ongoing. However, as stated, the methodology itself has allowed for participants to self-determine what and how they engage with the project and I believe that it has upheld their mana.

My biggest learnings from this process are around making space and opening up for all our lived realities as Indigenous Peoples. We have all journeyed our own whānau, hapu and iwi paths through colonisation and where we all stand today is a reflection of this. As we are not homogenous, our methodologies and responses to the world will also not be.

\section{Accepted 7 September 2020}

Published 3 November 2020

\section{References}

Anderson, N. (1923). The Hobo: The sociology of the homeless man. University of Chicago Press

Bateson, G., \& Mead, M. (1942). Balinese character; a photographic analysis. New York Academy of Sciences.

Bishop, R. (1998). Freeing ourselves from neo-colonial domination in research: A Maori approach to creating knowledge. International Journal of Qualitative Studies in Education, 11(2), 199-219.

Bochner, A., \& Ellis, C. (2016). Evocative autoethnography: Writing lives and telling stories. Routledge.

Brown, D. (2008). "Ko to ringa ki nga rakau a te Pakeha"Virtual Taonga Maori and museums. Visual Resources, 24(1), 59-75.

Ellis, C. (1999). Heartful autoethnography. Qualitative Health Research, 9(5), 669-683.
Ellis, C. (2004). The ethnographic I: A methodological novel about autoethnography (Vol. 13). Rowman Altamira.

Else, A. (1993). Women together: A history of women's organisations in New Zealand: Ngā rōpū wāhine o te motu. Wellington, NZ: Historical Branch, Department of Internal Affairs.

Harper, D. (2003). Framing photographic ethnography: A case study. Ethnography, 4(2), 241-266.

hooks, B. (1989). Talking back: Thinking feminist, thinking black. South End Press.

Jackson, M. (2013). Research and the colonisation of Maori knowledge. He Pukenga Korero, 4(1), 69-76.

Jenkins, K., \& Pihama, L. (2001). Matauranga wahine: Teaching Maori women's knowledge alongside feminism. Feminism \& Psychology, 11(3), 293-303.

Johnston, P., \& Pihama, L. (1994). The marginalisation of Maori women. Hecate, 20(2), 83-97.

Kermoal, N. (2010). The nationalist gaze of an Aboriginal artist. In B. Hokowhitu (Ed.), Indigenous identity and resistance: Researching the diversity of knowledge (pp. 169-178). Otago University Press.

Kidd, J., \& Finlayson, M. (2009). When needs must: Interpreting autoethnographical stories. Qualitative Inquiry, 15(6), 980-995.

Kovach, M. (2010). Conversation method in Indigenous research. First Peoples Child \& Family Review, 5(1), 40-48.

Lee, J. (2009). Decolonising Māori narratives: Pūrakau as method. Kaupapa Rangahau: A Reader, 91. Retrieved from http://www.review.mai.ac.nz/mrindex/MR/article/ download/242/242-1618-1-PB.pdf

Lorde, A. (2018). The master's tools will never dismantle the master's house. UK: Penguin.

Matahaere-Atariki, D. (1997). Interrogating speech in colonial encounters: Native women and voice (Unpublished master's thesis), Massey University, Palmerston North, New Zealand.

Mello, R. A. (2002). Collocation analysis: A method for conceptualizing and understanding narrative data. Qualitative Research, 2(2), 231-243.

Mikaere, A. (1994). Maori women: Caught in the contradictions of a colonised reality. Waikato Law Review, 2, 125-149.

Mills, M. (2009). Pou Rewa: The liquid post, Maori go digital? Third Text, 23(3), 241-250.

Murphy, N. (2013). Te awa atua: Menstruation in the pre-colonial Maori world: An examination of stories, ceremonies and practices regarding menstruation in the pre-colonial Māori world. Whakatane, NZ: He Puna Manawa.

O’Regan, H. (2001). Ko Tahu, ko au: Kāi Tahu tribal identity. Christchurch, NZ: Horomaka Publishing.

Pardington, F. (2013). Towards a kaupapa of ancestral power and talk (Unpublished doctoral thesis). The University of Auckland, Auckland NZ.

Said, E. W. (1979). Orientalism. Vintage.

Simpson, L. (2011). Dancing on our turtle's back. Arbeiter Ring Publishing.

Smith, L. T. (2013). Decolonizing methodologies: Research and indigenous peoples. Zed Books. 


\section{ORIGINAL ARTICLE}

\section{THEORETICAL RESEARCH}

Somerville, A. (2010). My poetry is a fire. In Wineera and Sullivan writing fire from Hawai'i. In B. Hokowhitu et al. (Eds.), Indigenous identity and resistance: Exploring the diversity of knowledge (pp. 37-54). Otago University Press.

Social Workers Registration Board. (2020). The SWRB ten core competence standards. Retrieved from https://swrb. govt.nz/social-workers/competence/core-competencestandards/

Spivak, G. C. (1988). Can the subaltern speak? In R. Morris (Ed.), Can the subaltern speak? Reflections on the history of an idea (pp. 21-78). Columbia University Press.

Wang, C., \& Burris, M. A. (1997). Photovoice: Concept, methodology, and use for participatory needs assessment. Health Education \& Behavior, 24(3), 369-387.

Wanhalla, A. (2015). In/visible sight: The mixed-descent families of southern New Zealand. Bridget Williams Books.

Williams, J. (2004). E pākihi hakinga a kai: An examination of pre-contact resource management practice in Southern Te Wāi Pounamu (Unpublished doctoral thesis). University of Otago (Te Whare Wānanga o Otāgo), Dunedin, New Zealand.

Wynter, S. (2003). Unsettling the coloniality of being/ power/truth/freedom: Towards the human, after man, its overrepresentation-An argument. CR: The New Centennial Review, 3(3), 257-337.

Yegenoglu, M. (1998). Colonial fantasies: Towards a feminist reading of Orientalism: Cambridge University Press. 